\title{
The role of sulphur during partial melting of eclogite in the cratonic mantle: constraints from experiments and mantle xenoliths
}

\author{
Sara Burness ${ }^{1}$, Katie A. Smart ${ }^{1}$, Gary Stevens ${ }^{2}$, Sebastian Tappe ${ }^{3}$ \\ ${ }^{1}$ School of Geosciences, University of the Witwatersrand, Johannesburg, South Africa; \\ sara.burness1@gmail.com, katie.smart2@wits.ac.za \\ ${ }^{2}$ Centre for Crustal Petrology, Stellenbosch University, Stellenbosch, South Africa, gs@sun.ac.za \\ ${ }^{3}$ University of Johannesburg, Auckland Park, South Africa, sebastiant@uj.ac.za
}

\section{Introduction}

Sulphide- and carbon-bearing melts play an important role as metasomatic agents within the cratonic mantle lithosphere, and may be linked to processes including diamond formation (Griffin et al., 2003), metal transport (Arndt et al., 2005) and the deep carbon cycle (Tappe et al., 2017). While the influence of C-bearing fluids on the lithospheric mantle is under continuous investigation (e.g. Dasgupta et al., 2004), the activity of S-bearing fluids and their role in diamond formation is less well constrained (Mungall and Brenan 2014). Sulphide minerals are key to the mantle S cycle. They control the platinum group element (PGE), siderophile and chalcophile element budgets, and their behaviour during partial melting controls the movement of these economically important metals. Here we present a case study of eclogite metasomatism by S+C-bearing fluids, by comparing new experimental work with geochemical investigations of sulphide-bearing eclogite xenoliths from several kimberlite occurrences on the Kaapvaal craton, South Africa. The focus of this study is to delineate the activity of S on the melting behaviour of eclogite and the relationship between sulphide-melt formation relative to carbonate \pm silicate melt formation. Our findings add to the knowledge of volatile-bearing solidii in the upper mantle, the partitioning nature of various major and trace elements between the silicate residuum, possible sulphide residuum, and miscible or immiscible silicate + carbonate melts and S-melts. A complementary investigation of sulphide-bearing eclogite xenoliths may serve as a benchmark for the processes of volatile-bearing metasomatism studied here.

\section{Melting of $\mathrm{C}+\mathrm{S}$-bearing MORB at upper mantle conditions}

In order to investigate the influence of C-O-H-S bearing fluids on mantle processes, we present results from partial melting experiments that constrain the near-solidus phase relations of $\mathrm{S}$ - and C-bearing eclogite from 2.0 to $3.5 \mathrm{GPa}$ and 1050 to $1300^{\circ} \mathrm{C}$. A synthetic MORB-like composition created from reagent grade silicate and carbonate powders was fired into a glass at $1400^{\circ} \mathrm{C}$ before being doped with 5wt.\% synthetic pentlandite $\left(\mathrm{Fe}_{0.93} \mathrm{Ni}_{0.17} \mathrm{Cu}_{0.03} \mathrm{~S}_{1.10} ; \mathrm{Metal} / \mathrm{Sulphur}=1.12 ; \mathrm{Ni} /(\mathrm{Fe}+\mathrm{Ni})=0.15\right)$ and, to foster melt detection, various proportions of $\mathrm{CO}_{2}(0.5$ and $15 \mathrm{wt} . \%)$ in the form of $\mathrm{CaCO}_{3}$. The starting compositions were placed in graphite-lined PdAg capsules and experiments were conducted using nonend loaded piston cylinder apparatus with a run time of 24 hours. The silicate experimental products consist of euhedral to subhedral garnet and omphacitic cpx \pm coesite, \pm zircon and \pm anorthite (Fig. 1), typically $\leq 15 \mu \mathrm{m}$ in size. Both sulphide liquid (e.g., $\mathrm{Fe}_{1.0} \mathrm{Ni}_{0.1} \mathrm{Cu}_{0.006} \mathrm{~S}_{1.12}$; Metal/Sulfur = 0.93; $\mathrm{Ni} /(\mathrm{Fe}+\mathrm{Ni})=0.09)$ and MSS (e.g., $\left.\mathrm{Fe}_{0.78} \mathrm{Ni}_{0.22} \mathrm{Cu}_{0.05} \mathrm{~S}_{1.26} ; \mathrm{Metal} / \mathrm{Sulphur}=0.84 ; \mathrm{Ni} /(\mathrm{Fe}+\mathrm{Ni})=0.22\right)$ are precipitated during the partial melting of eclogite. Phase relationships (Fig. 1) show distinct rounded globules of sulphide melt $\left(\mathrm{L}_{S}\right)$ which are texturally immiscible to both silica and silica dominated melts. MSS form discrete sub-angular grains that are usually $\geq 15 \mu \mathrm{m}$ in size. The location of the sulphide solidus is plotted in Fig. 2 along with carbonated eclogite solidii (1 and 2), a $\mathrm{CO}_{2}$-free eclogite solidus and the near-solidus phase assemblages. $\mathrm{CO}_{2}$-rich vapour is inferred as the main medium of carbon at low pressure in experiments with $5 \mathrm{wt} . \% \mathrm{CO}_{2}$. 


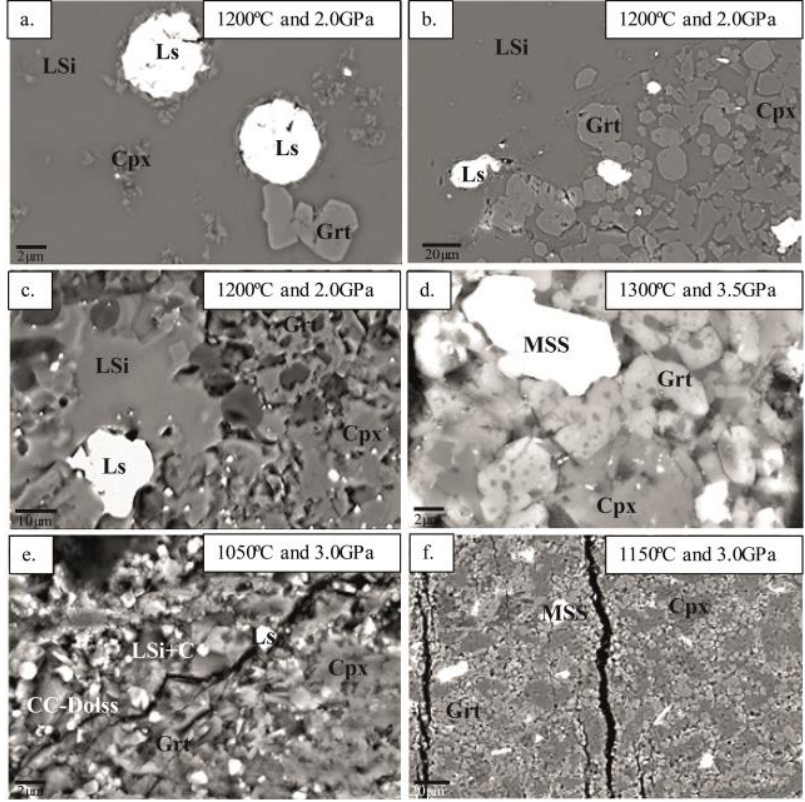

Figure 1: Select BSE images of the experimental run products. Cpx, clinopyroxene; Omp, omphacite; Diop, diopside; Grt, garnet; Zrn, zircon; An, anorthite; $\mathrm{CC}_{-D_{\mathrm{ss}}}$ calcio-dolomitic solid solution; MSS, massive sulphide solid solution; Melts, $\mathrm{L}_{\mathrm{Si}}=$ silica-rich liquid, $\mathrm{L}_{\mathrm{Si}-\mathrm{C}}=$ silica \pm carbonate liquid, $\mathrm{L}_{\mathrm{S}}$ $=$ sulphide liquid.

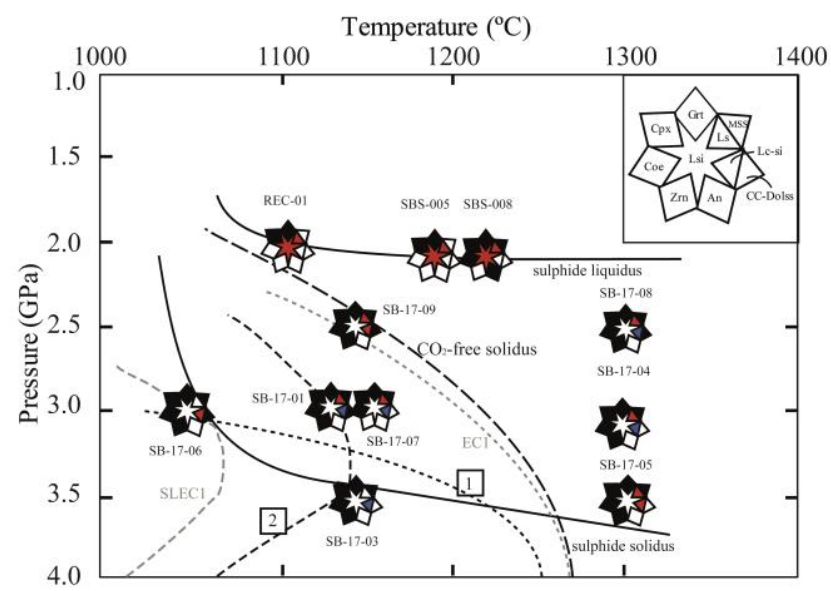

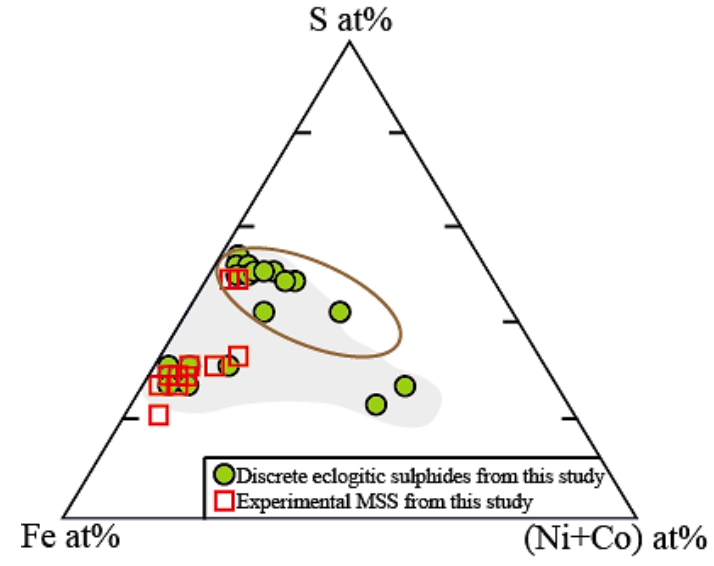

Figure 3: Reconstructed bulk eclogite xenolith sulphides and experimentally produced MSS from this study plotted in a $\mathrm{Fe}-\mathrm{S}-(\mathrm{Ni}+\mathrm{Co})$ ternary diagram. Grey shaded area represents sulphides from eclogite xenoliths and E-type diamond sulphide from the Kaapvaal Craton. The grey circle encapsulates sulphides which have been affected by oxidation.

Figure 2: Experimental P-T phase diagram for $\mathrm{S}+\mathrm{C}$-bearing MORB. Phase abbreviations as in Fig. 1. Black fields indicate the presence of a mineral phase, red fields a quenched liquid phase (melt), blue fields $\leq 2$ vol. $\%$ of a liquid phase plus voids inferred to represent $\mathrm{CO}_{2}$-gas pockets. Sulphide solidus and liquidus curves are plotted using thick solid lines. 1. carbonated eclogite solidus (15wt.\% $\mathrm{CO}_{2}$ ) and 2. carbonated eclogite solidus (5wt.\% $\mathrm{CO}_{2}$ ). EC1 (15wt.\% CO ; Yaxley and Brey, 2003), SLEC1 (5wt.\% $\mathrm{CO}_{2}$; Dasgupta et al. 2004), $\mathrm{CO}_{2-}$ free solidus $\left(\mathrm{CO}_{2}\right.$-free eclogite, Litasov and Ohtani 2010).

\section{Textural and compositional characteristics of sulphides in mantle eclogite xenoliths}

Nineteen eclogite xenoliths from the Jagersfontein, Roberts Victor, Kamfersdam, Swartruggens and Premier kimberlites were selected for study based on the identification of sulphides. Sulphides form discrete polyphase assemblages (e.g. $\mathrm{Po}+\mathrm{Pn}+\mathrm{Cp}$ ) that occur as inclusions in clinopyroxene along with interstitial grains. The reconstructed sulphides are similar in composition to some sulphides present in mantle eclogites, eclogite-type diamond inclusions as well as the MSS produced in our experiments (Fig. 3). The natural sulphides (MSS) can contain up to hundreds of ppm Mo, $\mathrm{Zn}, \mathrm{Ag}$, and Pb, <100 ppm of $\mathrm{Ag}$ and $\mathrm{V}$, whereas $\mathrm{Pd}, \mathrm{Ru}, \mathrm{Rh}, \mathrm{Pt}$, and Au concentrations are <10ppm.,Os and Ir are present from bdl to $<0.3 \mathrm{ppm}$ and $<0.6 \mathrm{ppm}$, respectively. $\mathrm{Zn}, \mathrm{Mn}$ and $\mathrm{Co}$ are the most abundant of the sulphide trace elements (e.g. $\mathrm{Zn}$ ranges in concentration from $\sim 1.8 \mathrm{ppm}$ to $\sim 1 \mathrm{wt} \%$ ). Most eclogite xenoliths studied here have oceanic crustal protoliths, based on normalized REE patterns, Eu anomalies, and oxygen isotope compositions $\left(\delta^{18} \mathrm{O}\right.$ values from 3.3 to $10.4 \%$ ). 


\section{Links to mantle metasomatism in the presence of $\mathrm{C}+\mathrm{S}$ - bearing fluids/melts}

Our study shows that S melts+MSS are the first to appear upon melting of a S+C-bearing high-pressure MORB (Fig. 2). There is a small temperature difference between the $\mathrm{S}$ and $\mathrm{S}+\mathrm{C}$ solidii at the pressures investigated, but this temperature difference may not easily be distinguished during incipient melting. The experimental S-melts and solid MSS are enriched in siderophile and chalcophile elements and likely PGEs (Bockrath et al., 2004), show a striking similarity to sulphide inclusions in E-type diamonds (Fig. 3; Deines and Harris, 1995) and texturally and compositionally resemble the sulphides in our studied eclogite xenoliths. The experimental S-melts and MSS also appear to form high-angle contacts with silicates and $\mathrm{Si}+\mathrm{C}$ melts, or discrete globules within highly polymerised silicate melt (Fig. 1), such that the immiscible nature of our experimental MSS supports the 'nugget effect' of sulphides observed in mantle eclogite nodules. In summary, our study suggests that S-melts alone may not be effective metasomatic agents in the cratonic mantle. However, since $\mathrm{S}+\mathrm{C}$ melts are likely produced together during mantle melting, carbonatitic melts with appreciable $\mathrm{S}$ may instead be effective ways to concentrate and mobilize PGE minerals within the CLM, and due to the overlap of sulphide DIs and our experiments, $\mathrm{S}+\mathrm{C}$ melts may be effective diamond-growth media.

\section{References}

Arndt N, Lesher CM, Czamanske GK (2005) Mantle-derived magmas and magmatic Ni-Cu-(PGE) deposits: 5-24

Bockrath C, Ballhaus C, Holzheid A, (2004) Fractionation of the platinum-group elements during mantle melting. Science 305 (5692): 1951-1953

Dasgupta R, Hirschmann MM, Withers AC, (2004) Deep global cycling of carbon constrained by the solidus of anhydrous, carbonated eclogite under upper mantle conditions. Earth and Planetary Science Letters 227(1); 73-85

Deines P, Harris JW (1995) Sulfide inclusion chemistry and carbon isotopes of African diamonds. Geochimica et Cosmochimica Acta 59(15): 3173-3188

Griffin WL, O’Reilly SY, Abe N, Aulbach S, Davies RM, Pearson NJ, Doyle BJ, Kivi K (2003) The origin and evolution of Archean lithospheric mantle. Precambrian Research 127(1): 19-41

Litasov K, Ohtani E (2010) The solidus of carbonated eclogite in the system $\mathrm{CaO}-\mathrm{Al} 2 \mathrm{O} 3-\mathrm{MgO}$ $\mathrm{SiO} 2-\mathrm{Na} 2 \mathrm{O}-\mathrm{CO} 2$ to $32 \mathrm{GPa}$ and carbonatite liquid in the deep mantle. Earth and Planetary Science Letters 295(1): 115-126.

Mungall JE, Brenan JM (2014) Partitioning of platinum-group elements and Au between sulfide liquid and basalt and the origins of mantle-crust fractionation of the chalcophile elements. Geochimica et Cosmochimica Acta 125: 265-289

Pertermann M, Hirschmann MM (2003) Partial melting experiments on a MORB-like pyroxenite between 2 and $3 \mathrm{GPa}$ : Constraints on the presence of pyroxenite in basalt source regions from solidus location and melting rate. Journal of Geophysical Research: Solid Earth 108(B2)

Schrauder M, Navon O (1994) Hydrous and carbonatitic mantle fluids in fibrous diamonds from Jwaneng, Botswana. Geochimica et Cosmochimica Acta 58(2): 761-771

Tappe S, Romer RL, Stracke A, Steenfelt A, Smart KA, Muehlenbachs K, Torsvik TH (2017) Sources and mobility of carbonate melts beneath cratons, with implications for deep carbon cycling, metasomatism and rift initiation. Earth and Planetary Science Letters 466:152-167

Yaxley GM, Brey GP (2004) Phase relations of carbonate-bearing eclogite assemblages from 2.5 to 5.5 GPa: implications for petrogenesis of carbonatites. Contributions to Mineralogy and Petrology 146(5): 606-619 